\title{
Examining Sanctions on Syria: Possibilities for Effectiveness Based on a Spatial Model Bader Mustafa
}

Department of Political Science and International Relations

Institute of Social Sciences

Istanbul Aydin University

E-mail: badermustafa86@gmail.com

Turkey

\section{ABSTRACT}

Sanctions are one of the most important tools used in foreign policy after World War II. Moreover, sanctions" subject is keeping to be a controversial one, even though the international institutions and powerful states are using sanctions since the beginning of the 20th century. However, the scientific and political community could not reach a clear-cut stand on sanctions" effectiveness. This ambiguity happens for many reasons: the humanitarian consequence of sanctions, the possibilities of achieving their goals, and the political disagreement between great powers like the use of the VETO right in the Security Council. Regarding Syria as the government and entities connected to it, are facing intensive sanctions starting from 2011 especially from the European Union, and the United States of America. Nevertheless, those sanctions were not the first case that Syria is facing sanctions in its history. Therefor his paper would investigate the cases of sanctions that been imposed on Syria, from 1979, until 2011 and after, according to (the spatial model conclusions, which suggests three directions for the result of sanctions; first sanctions success possibility unilaterally or multilaterally is high, if the sanctioned system is democratic and has a strong relationship with the sender. The second is; sanctions may have a positive result in changing an authoritarian regime if the nature of the sanctions were not fatal to the existence of the regime. The third is that sanctions on authoritarian regimes would fail if they target its existence and would result in overthrowing it.

\section{Keywords: Sanctions, Impact of Sanctions, Iraq, Libya, Syria.}

\section{Introduction}

The issue of sanctions is a controversial one, even though the use of sanctions as a tool of foreign policy goes back for ages. Most scholars agree that the case of "Megarian decree" 432 B.C., was the first use of sanctions as a foreign policy tool, when Sparta, the city-state declared an opponent of the Athenian Empire, was aided by the Megara Empire, Pericles, an orator in Athens approved a trade embargo between the Athenian Empire and the Megara. In modern history sanctions started to be discussed as a mean of establishing prominent peace and preventing wars, the beginning was with the League of Nations, but the experience of the institution was not so bright due to the weak power of the institution and also the rise of tension between great powers like Germany, and Japan, Russia, Italy, and the U.S.A. After WW2 sanctions were stated in the newly established international institution, the United Nations, but again due to the bipolar nature of international politics, sanctions were not used very actively, and the UN reported sanctions more actively after the collapse of the Soviet Union. So, in most cases sanctions were imposed unilaterally, by the U.S. and its allies.

Besides debating the development of sanctions in international politics, this paper will present definitions of sanctions, and types of sanctions. The paper will explore examples of sanctions on Iran and Libya. Then the paper will focus on the first sanctions imposed on Syria in 1979, based on Syria's support of the Palestinian resistance, and its involvement in the regional conflicts through supporting non- state-actor's groups in the region. Again in 1986, more collective sanctions were imposed on Syria, after being accused of attempting to explode "Israeli El Al 016 flight." However, during the 1990s, Hafiz al-Assad tried to decrease tension with the western world until he died in 2000. After Hafiz"s death his son Bashar took the presidency, and again for the reason of preserving military presence in Lebanon and supporting Hezbollah, Syria faced sanctions from the U.S, in 2003. The start of the Syrian crisis in 2011, pushed Syria to face more extensive sanctions from the U.S, and EU, which are continuing until now, and increasing rapidly and reached more than 1200 sanction cases.

\section{Literature Review}

After World War I, and the formation of the League of Nations, sanctions started to be discussed as a means of enforcement by the international community, especially after the announcement and suggestion of the U.S. President Woodrow Wilson in 1914, to the League of Nations. Wilson stated that "imposing sanctions would help to keep the world war-free", also Wilson called sanctioning measurement "a peaceful, silent and real solution”. (UNOG Registry, 2016). Wilson's proposals were considered in Treaty of Versailles principles but were not expressed directly as sanctioning in words, but more stressing on peaceful means to solve disagreements between countries. This situation changed after World War II, and the formation of the United Nations, which stated in its VI, VII, VIII, and XII, chapters the right of the organization to take binding decisions against states that 
threaten the international security, requiring all states to adopt certain measures, contain no forcible and permanent measures. "Upon the call of Members of the United Nations to apply such measures not involving the use of armed force "once it has determined "the existence of any threat to the peace, breach of the peace, or act of aggression. (Talmon, 2005). However, even though the UN, was formed in 1945, the first UN sanctions took place in 1963, against the apartheid system of South Africa. In general, the UN and the Security Council were not able to be very active regarding sanctions before the dissolution of the Soviet Union. After the collapse of the Soviet Union, the United Nations started to sanction many countries, especially regarding internal conflicts. However, as a result of the use of VETO in the UN, most of the sanctioning cases were imposed by the U.S and EU. The U.S lead of imposing sanctions also raised another subject, which is the use of sanctions as a foreign policy tool.

\section{Definition and type of sanctions}

Sanctions are defined in many, ways most of them are describing them as a measurement that should not be violent, and aim to change a targeted country or entity`s behavior, so in this direction and according to the Chapter VII of the United Nations Charter. Sanctions encompass a broad range of enforcement options that do not involve the use of armed force" (United Nations News, 2016). Another international institution is the European Union, which did not define sanctions explicitly, but sanctions are serving a similar goal, which is implementing the decisions either of the UN Security Council or the Council of the EU on actors that violate human rights or threatening the international security (European Parliament, 2018). In brief, sanctions are defined as punishing means used to safeguard peace and "security and to promote democracy and human rights, in intention to stop the violation of international law. (Clifton, Bapat, Kobayashi, 2014)". As for the types of sanctions are can differ regarding their scale, so they either targeted sanctions, aiming to hurt a specific institution or persons of the targeted country, like U.S sanctions on some Russian administrations and companies. On the other hand, they can be comprehensive sanctions when they are aimed against the all structure of the targeted entity, like the case of U.S and U.N sanctions on Iraq during Saddam Hussein rule. Also, sanctions are classified according to the number of senders, so they either are unilateral sanctions, by one sender state or can be multilateral sanctions, when a group of senders is agreeing on sanctioning an entity.

\section{Attitudes toward sanctions}

Using sanctions as a tool, either by international institutions or unliterary by superpowers especially by the United States is still an argumentative subject. The general arguments about sanctions are usually progressing in light of three main questions; 1 - Are sanctions effective in changing the country's behaviors? 2- How much do they decrease or increase humanitarian suffering in targeted countries? 3- Are they foreign policy engineering tools, or honest tools to stop international law violations? In this regard (Hufbauer et al. 2009), are among scholars who have written one of the most comprehensive books regarding sanctions, and known as HSE data, are considering sanctions as one of the tools for enforcing targeted government to behave according to international law. They do recommend the use of sanctions by saying "even if the sanctions made little or no contribution by HES test. That does not mean it was a mistake to impose them. As for the effectiveness of sanctions, "HSE" explains them in three points; first: with limited success, when compelling sanctions may cost the political and security of the targeted country more than resisting them. Second: sanctions would fail, when their main goal is not to achieve real changes in a target country's behaviors, giving the example of U.S sanctions on China after the 1989 massacre in Tiananmen Square. Third: sanctions sometimes fail because sender countries have different and conflicted advantages and goals, like the cases of the European position toward U.S sanctions on Iran and Russia. The research is concluding that about $34 \%$ of sanctions are at least partially successful, which means that real success is very lower than this percentage. When we take into considerations that most attempts to stop military adventures were not successful, also it was not successful to prevent countries like; Argentina, Pakistan, India, and South Africa from becoming nuclear powers, successes were more with very weak countries or countries that have to some degree democratic system. Another comprehensive work like (HES data) is the work of Bapat \& Morgan (2009), which is known as (TIES 4.0) data. In their work, they are comparing multilateral and unilateral sanctions, they found that "based on Spatial models, the success of sanctions depends on the number of issues, the main one is whether an international institution is involved or not since the presence of international institutions could produce more coercive power and increase the likelihood of sanctions success". Comparing the two studies TIES and HES, they reached the different rate of success cases HSE had reached $34 \%$ of success, as for TIES it was less and reached $23 \%$.

\section{Iran and Libya sanctions}

The Iranian very clear example of most types of sanctions; multilateral sanctions by the United Nations, and unilateral sanctions by the United States of America. Moreover, Iran is a good example for the case of the disagreement between senders themselves. The European Union is in most cases in favor of easing sanctions on Iran, on the other hand, the United States, in most cases wants an increase of sanctions. Moreover, the Iranian examples show the reality that authoritarian regimes would cooperate with the sanctions senders when the result of the cooperation will lead to the change of the regime, or at least changes its nature on all levels of governance. 
Iran's relations with the western world was not forever in tension like it is now, but it has seen many ups and downs during the past century. Houghton, in his review for three books regarding the "U.S-Iranian Relations, Future and Past," discusses this relation starting from the "D"Arcy oil concession of 1901". Between the Shah of Persia and William Knox D"Arcy", the Iranian oil was granted for Britain and later was replaced by U.S dominance. The foreign dominance of the Iranian national resources led to the rise of Mohammed Mossadegh in 1950. However, Mossadegh and as a result of his nationalizing policies was overthrown in a coup against him on August 19, 1953, in an operation led by the CIA and MI6. After overthrowing Mossadegh, the Iranian Shah was seen as U.S`s policy manager during the 1970s. The Shah depended increasingly on coercion instead of endorsement and eventually fled from Iran in 1979" After the Islamic Revolution succeeded in Iran (Houghton, D2014). Few years after the Islamic Revolution U.S, Department of State designated Iran as a state sponsoring terrorism in 1984, and the nuclear program became the main generator of sanctions on Iran, besides many sanctions regarding the Iranian efforts to develop ballistic missiles (Patrikarakos, D, 2012). Eventually, Iran and the western countries reached an agreement called the Joint Comprehensive Plan of Action (JCPOA), on 18 October 2015, through the work of the P5+1, the group includes the United States, the United Kingdom, France, Russia, China, and Germany. Iran agreed to take measures to limit its nuke program in exchange for a major relaxing of penalties from the US, the UN, and the EU. Many steps to word implementing the agreement take place from both sides; the international community, and Iran, but the deal started to face obstacles after Donald Trump came presidency in the US, in 2017, Trump withdrew from the deal with Iran in May 2018. (Patrikarakos, D, 2012).

Another two main drivers behind the Iranian-US tension were the Iranian-Israel hostile relations and the Iranian operation and management of many violent non-state actors. Israel is seeing Iran`s regime and its military capabilities as a threat to its existence, Israel's attitude toward Iran based on many public statements of Iranian leaders about annihilating Israeli from existence, like the statement of previous Iranian President Ahmadi Nejad made the statement in 2006, "Jerusalem Cause which, includes annihilating Israel in one storm". The other reason for the Iranian and U.S hostile relations also resembles in some activities of the Iranian huge group of nonstate actors across the region: Iraq, Syria, Lebanon, Yemen, Palestine, and Afghanistan. The Iranian government knows that changing her behavior according to what the US is demanding will end with changing the Iranian political system, so according to the conclusions of HES, and TIES, the more logical decision of the Iranian ruler is to resist the sanctions. The table below gives some idea about the changes that take place in Iran`s GDP growth and can give a small hint of sanctions effects on the Iranian economy.

(Iran GDP - Gross Domestic Product 2018, 2020)

\begin{tabular}{|c|c|c|}
\hline \multirow{2}{*}{ Date } & Annual GDP & \multicolumn{2}{c|}{ GDP } \\
& & Growth (\%) \\
\hline 2018 & 446,105 M. \$ & $-5.40 \%$ \\
\hline 2017 & 430,709 M. \$ & $3.70 \%$ \\
\hline 2016 & 404,445 M. \$ & $12.50 \%$ \\
\hline 2015 & 375,404 M. \$ & $-1.60 \%$ \\
\hline 2014 & 423,409 M. \$ & $3.20 \%$ \\
\hline 2013 & 396,408 M. \$ & $-0.30 \%$ \\
\hline 2012 & 389,199 M. \$ & $-7.70 \%$ \\
\hline 2011 & 577,214 M. \$ & $3.10 \%$ \\
\hline 2010 & 482,384 M. \$ & $5.70 \%$ \\
\hline 2009 & 410,557 M. \$ & $0.00 \%$ \\
\hline 2008 & 406,212 M. \$ & $-0.10 \%$ \\
\hline 2007 & 351,769 M. \$ & $6.70 \%$ \\
\hline 2006 & 270,333 M. \$ & $5.30 \%$ \\
\hline 2005 & 228,180 M. \$ & $5.10 \%$ \\
\hline
\end{tabular}


The Libyan case is one of the rare cases of sanctions, since it finishes with the cooperation of the authoritarian regime, with the sanctions senders. The Libyan relations with the U.S goes back when the Tripolitan government formally recognized U.S. independence, on November 4, 1796, when Tripoli was part of the Ottoman Empire. Before and after the collapse of the Ottoman Empire Libya was occupied by Italy from 1912 till 1942, later the British and French occupation between 1943 and 1951 when it gained its independence. The United States recognized the United Kingdom of Libya in the same year of its independence in 1951. The nature of the relationship between Libya and the western world started to change after Colonel Muammar Gadhafi`s takeover of the leadership of the country on September 1, 1969. In five years period from Gadhafi's takeover of the control in Libya, finished the U.S military existence at Libya"s Wheelus Air Force Base until 1971, and he started the process of nationalizing the American and British Oil production companies.

In 1973, Gadhafi made an appeal to the Arab states to cut oil from America, and in 1974, Libya finished the nationalization process. Politically Gadhafi at the beginning was an opponent of international communism, particularly "Soviet imperialism". However, as Gadhafi"s son, Saif Aleslam Gadhafi, pointed out in 2003, "Trouble started when under Gadhafi"s leadership, the new government, tried to claim national political sovereignty, and removed the US military bases from our territory." (Africa Gate News, 2019). Regionally and internationally Colonel Muammar Gadhafi and from the first years of his rule showed support to Palestinian resistance groups, and some other violent groups around the world, moreover Libya engaged in many international bombing attacks, "like the Lockerbie bombing on December 21, 1988, and the explosion of a French UTA airplane over Niger in 1989" (Zoubir, Y. 2006). Libya was also involved in direct military operations against neighborhood countries like the case of the Libyan - Chadian war. Gadhafi also supported the Black September Movement, which carried out the Munich massacre in the 1972 Summer Olympics, and offered all support either training camps or financing the Palestinian armed organizations in 1972 and later, and logistics for the Irish Republican Army in 1973, Moreover planning the 1986 Berlin nightclub blasting, (Crisis Group, 2020).

As a reason of the disagreements between Libya and the western world, and the Libyan engagement in violent acts, led the later to face many sanction laws and decisions, the main ones of them are: in the 1970s, export controls on military and civil aircraft were imposed, also in 1979, the U.S. designated Libya a "State Sponsors of Terrorism ". Moreover, from 1986 until 2004, the U.S frozen assets of the Libyan government and affiliated individuals and entities. International sanctions on Libya were imposed by the United
Nations in 1992, through resolution 731. UN sanctions were suspended after Libya handed over individuals responsible for the Lockerbie attack for the trial to the U.K, in 1999. In addition, from 1996 to 2006; Legislation is known as the 1996 Iran-Libya Sanctions Act, allowed the U.S government to sanction companies doing business with or in Libya. (Bangura A, 2014, \& United Nations Security Council, Resolution 731). The military coup led by Muammar Gadhafi was during the highest period of tension between the United States, and the Soviet Union. However, even though Gadhafi, was not in favor of the USSR, but his engagement in many violent attacks on the interests of the western countries, and their citizens directly, put him in confrontation with the EU, and the US, and many other Arab countries, also made him widely recognized as the primary funder of international terrorism in the mid1980s.

The factors that were behind the change of Gadhafi attitude regarding cooperation with the Western countries, were the isolation from the international community, and the collapse of the Soviet Union in 1991, also the changes that happened to the Palestinian groups and neighbouring countries, and the emergence of peace making desire from those parties with Israel. All of those factors were reasons for Gadhafi change during the 1990s, later the 11 September 2001 attacks, was another important driver when Gadhafi released that the U.S would use the hard power against countries that were accused of sponsoring international terrorism, so he offered counterterrorism and intelligence cooperation with the U.S. As a result of positive changes in Libyan policies, most of the sanctions on Libya was removed, and a cooperation period governed the relationship between Libya and the western countries from 2001 until 2010.

According to the presented opinions of scholars about sanctions, we may present that the work of Bapat \& Morgan (2009), known as (TIES 4.0) data, which is based on the "spatial models", is the one that can explain the case of Iran, and Libya. In the case of Iran; when sanctions were aiming to change Iran`s behaviours, and the result of removing them was for the Iranian regime's benefit. Iran did cooperate after resisting for a period, but after 2018, and the return to harsh sanctions, the Iranian regime saw them as targeting its existence and refused to cooperate more. Moreover, a clearer case with the Libyan government, when Libya reached a conclusion that removing sanctions is in its interests, and the international atmosphere was in favour of the sending countries, the Libyan government chose to cooperate.

\section{Syrian case}

\section{Syria political and governmental formation}

After the First World War, Syria was mandated by the French until 1943 and took full independence in 1946. After Syria gained her independence it went through five main phases; the first was from independence until 1963, and it 
witnessed political and governance shakes, through many military coups, also Syria witnessed a failed attempt of unity with Egypt, regionally there were many projects formed and run by the U.S, or the UK, like the Middle East Leadership Project, the Baghdad Pact. The UK and U.S tried to conjoin Syria also as a part of those projects, but could not succeed in this aim. The second started in 1963, after a coup d"état by the al-Baath party took place and continued until the coup of Hafez al-Assad in 1970. It was marked by internal disagreements in the al-Baath party, and wars between Syria and Israel. The third phase started from the coup of Hafez alAssad in 1970, until his death in 2000, this period witnessed the Arab-Israeli War and the Syrian intervention in Lebanon in 1975. Besides the peace deals between Israel and some Arab countries. The Iraqi-Iran war in 1980. Israel invasion of Lebanon in 1982. In 1982 Syrian Hama connivance massacre. The collapse of the Soviet Union in 1991, first Gulf War 19901991. The fourth phase is starting from Hafez al-Assad's death in 2000 and the nomination of his son Bashar al-Assad to the presidency of Syria, until 2011 with the start of the Syrian crisis. The fifth and last phase is from 2011, until now, with the continuity of the crisis.

II. Unilateral U.S sanction in 1979, multilateral sanctions in 1986, and U.S. sanctions in 2003

International relations of the Republic of Syria in the late 1950s leaned toward the Soviet Union, and it was further advanced after the emergence of the al-Baath Party, which made socialism the ideology of the state. After the coup of Hafez al-Assad took place in 1970, Syria became one of the countries under higher Soviet influence at the climax of the cold war. The interventions of the Syrian regime in regional issues through violent methods, whether in Lebanon, Turkey, or Palestine, especially in the attempts of bombing western passenger airplanes, put Syria in a hostile relationship with the western block (Sloan and Anderson 604). The United States adopted a policy of enticement towards Syria in multiple ways, It further used containment and positive alignment of Syria on two levels: first by trying to engage Syria in security schemes allied to Washington in the region; second by offering economic aid. In this latter context, between $1950-1981$, the US offered around 627 million USD in aid for the Syrian state. (Congressional Research Service, M. Blanchard, \& M. Sharp, 2011). The situation, however, started to change after Syria's intervention in Lebanon and the shift that took place in the Syrian regime's approach to security matters. Furthermore, Hafiz Assad stepped forward in engaging the regional security files, by opening Syria, and Lebanon as a harbor for the Kurdistan Workers Party (PKK). These moves put Syria in face of U.S sanctions for the first time in 1979. Those reasons can be listed as:

The first was al-Assad's use of Palestinian commando groups to carry out operations against Israel. Second, he kept
Syrian troops in Lebanon where they were directly involved in Lebanese internal strife. The use of violent organizations guaranteed the Syrian regime a leading role in regional security policies. (The International Institute for CounterTerrorism -ICT \& Reuven, 1998). The third reason was the process, and developments after the 1973 war, and the few years after which led to the peace agreements in the region between Egypt, Jordan, and Israel. The U.S managed very biased political negotiations conducted by her secretary of state at that time Henry Kissinger, who managed a bad negotiation process for the Arabs and in favor of Israel, which led to the isolation of Syria under the al-Assad rule, (Elseid Hussein, 2012). All of those reasons put Syria on the "States Sponsoring terrorism list", by the Department of States. According to the department, sponsoring terrorism states are the ones; offering direct or indirect support to international terrorism, and their credibility in assisting the US, to combat terrorism, in addition to the links between terrorism and the proliferation of weapons of mass destruction, (A. Rochefort, D. 2005). As for Syria 1979, sanctions did not affect the Syrian regime directly, and al-Assad was not in favor of changing his policies regarding supporting violent groups, or Palestinian groups, and that was obvious from Syrian more control of the Palestinian groups either in Syria or in Lebanon, (Jamal, 2015). In addition, al-Assad raised his support to Kurdistan Workers ' Party, in his fight against Turkey, besides supporting the Islamic Iranian revolution. Internally Hafiz al-Assad tightened his grip on the al-Bath party and later on the political life in Syria by forming the National Progressive Front (Syria), which was formed in 1972.

The second case Syria faced sanctions was regarding the "El Al 016 flight" known also as the Nezar Hindawi Affair. Hindawi was born in 1954 and worked as a journalist in Jordan before moving to London to be associated with a British girl, named Anne Marie Murphy. In April 1986, he was accused of being behind the attempted bombing of the Israeli El Al plane "Flight 016", which was landing as a transit at London's Heathrow Airport in Britain, coming from New York and heading to Tel Aviv on April 17, 1986 (Glass, 1986). After the bomb was discovered inside Murphy's bag. She claimed that she did not know that she was carrying explosives and that the package was given to her as a gift from her fiancé Nezar Hindawi. Meanwhile, Nezar heard that the bomb had been discovered and his girlfriend had been arrested. He went to the Syrian embassy in London requesting help, which he got, however, Nizar, on the next day, of April 18, 1986, surrendered to the British police. During the investigations, Hindawi said that the bombing attempt was carried out on the orders of a senior official in the Syrian Air Force Intelligence a year before the incident, (X. Clines, 1986). Hindawi was sentenced to 45 years in prison. 
Immediately after Hindawi was sentenced, the British government cut diplomatic relations with Syria, and Washington reduced its diplomatic representation. Britain also called on the rest of the European countries to take strict decisions against Syria, but not all European countries did agree to take this step. In addition, not all British officials agreed to tighten sanctions on Syria for several reasons, such as for the possible Syrian role in a peace process in the Middle East. In addition, it was considered a risky step with the presence of European and American hostages in Lebanon who were kidnaped by armed organizations, and the possibility that the sanctions in Syria would push Syria to offer to support the Palestinian and Lebanese armed organizations. Nevertheless, Hindawi incident pushed Syria to face her first multilateral penalties; Britain: Cut the diplomatic and commercial relations with Syria. America: Expanded controls on exports of any controlled material for national security purposes to Syria, as well as all aircraft, helicopters, and related parts and components. The abolition of the US-Syrian air transport agreement, and some other measures. Western European countries: The European Economic Community met at the end of 1986 and decided to impose a program of limited sanctions against Syria. Yet, Greece did not agree on sanctioning Syria, the measures included the ban on arms sales, stopping highlevel political visits, and reviewing the status of Syrian diplomatic missions, and intensifying security measures regarding the work of Syrian Arab Airlines. The European Parliament voted to withdraw development aid to Syria from the European Economic Community's 1987 budget (Bonn International Center for Conversion \& Kreutz, 2005). In Syria, Al-Assad was quick to respond to some European pressures. Hours after the European Economic community's decision, Syria took swift measures, so two French and one American hostage were released, and were delivered to Damascus, also al-Assad closed some of the offices of the Palestinian Abu Nidal Group. In the wake of these developments, the European Economic Community stated in 1987 that Syria"s position must be taken into account if a peace conference is to be organized in the Middle East.

"Economically, the Syrian crisis with Britain came in 1986, at a time when the Syrian economy was suffering from contraction and fluctuation, (Scott, 2016), because of the; Global economic crises, the drought season, reduced remittances from Immigrants, and the burden of paying off external debts. However, the economic effects of European sanctions appeared directly on the Syrian regime, the total value of exports was 6426 million in 1985, and decreased to 5198 million in 1986, as for imports they were 15570 million in 1985, and decreased to 10709 million in 1986. (Al-Himish, 2011, p. 225). During the crisis of El Al 016 flight and its consequences, it was clear that threatening and imposing collective sanctions on the Syrian government, severely affected the Syrian economy. Moreover, isolated the regime in a way pushed the Syrian government to change some of its behaviors, like controlling some of the Palestinian and Lebanese armed movements inside Syria and Lebanon. Nevertheless, they were not effective enough to stop Syrian interventions in other countries" issues like Lebanon politically or by supporting groups like Hezbollah and the Amal Movement, or the Kurdistan Worker Party in Turkey.

Hafiz Assad tried to lean his policies toward the US, after 1991, based on 1986, sanctions, and the regional isolation, and finally the collapse of the Soviet Union in 1991. So he participated in the first Gulf war against Iraq 1990-1991, also Syria changed its position regarding the peace with Israel, and engaged in a negotiation process with Israel that continued from 1992 until 1999. Those changes in Syria`s policy softened the U.S stand against Syria and Hafez al-Assad regime, but did not lead to removing the imposed sanctions on Syria, for its role in the Lebanon situation and continuing to support Palestinian resistance and Lebanon Hezbollah. After the Syrian president, Hafez al-Assad's death in 2000, his son Bashar al-Assad was inaugurated as president of Syria in 2000. An atmosphere of positive change rose, but only after one year, and on 11 September 2001 attack took place, again Syria was a target of the US, criticim for its role in Lebanon, and during U.S preparations for the war against Iraq. After the U.S, occupation of Iraq in 2003, the U.S accused Syria of sponsoring trans-border operations against U.S soldiers, and the Syria Accountability Act was issued in 2003 (Nuruzzaman, 2020). One year later the Lebanon prime minister Rafik Hariri was assassinated, again Syria was the most interested in suspect of conducting the operation. These events led to rising pressure on Syria, which eventually forced Syria to withdraw from Lebanon in 2005. In general, Syria faced isolation after 2003, until 2008, when some golf countries, France, and Turkey tried to help and improve the Syria situation, which worked well for a few years until 2011. In 2010 the Arab Spring was soon in Syria, the Syrian government responsible for the demands of a more democratic system and reforms was with intensive violence (Bosco, R. 2009).

\section{Sanctions on Syria after 2010}

The Arab Spring started in Tunisia in 2011 when Tunisians managed to topple the regime of Zein El Abidine Ben Ali who ruled them for over 23 years. The wave moved to Egypt where the people managed to topple the regime of Muhmmad Hosni Mubarak who ruled Egypt since 1981. In parallel, a popular revolution erupted in Libya against Muammar al-Gaddafi who ruled Libya for about 40 years, and another revolution erupted in Yemen against Ali Abdullah Saleh who ruled it since 1978. Protests in most of these countries managed to topple their governing regimes. Against this backdrop, the popular movement in Syria against the rule 


\section{(c) Center for Promoting Education and Research (CPER) USA}

www.cpernet.org

of the Assad family and its security and military system that lasted for over 50 years has started.

The popular protests in Syria started in February 2011 but quickly turned to become a popular war against the regime because of the suppression practiced by security and military forces against the revolted cities and towns. They killed hundreds of unarmed civilians in the squares during the protests and at homes. As the conflict expanded, opposition armed factions started to be formed to confront the Syrian government. The fighting extended and included the use of heavy weapons inside cities. Regional countries started to send their experts, whether to the side of the regime or to the other side. At that point, some quality changes would happen every now and again in the nature of the conflict taking place in the country. However, in 2013, the Islamic State in Iraq and Syria (ISIS) appeared and declared control over Mosul in Iraq, then in mid-2014, it assumed control over Raqqa in Syria. ISIS removed the borders between the two countries, becoming a self-proclaimed state with a territory under its control that is about $50 \%$ of the land area of Syria, and more than $30 \%$ of the land area of Iraq ("ISIS" on the first anniversary of the declaration of the "caliphate", 2015).

\section{Unilateral sanctions}

With the beginning of the Syrian regime's crackdown on the protests, the international community started to take some measurements against the Syrian government. Those measurements were from two types; one unilateral sanction that was imposed on Syria by individual countries, the second were multilateral sanctions, which were imposed by international organizations like the League of Arabs, and the European Union. The beginning was with the U.S, which issued an executive order on 29 April 2011, the order expended the old imposed sanctions, and imposed new sanctions within the framework of the "Syria Accountability Act". The new wave of measurements was against public institutions and individuals from the Syrian government. Soon later U.S sanctions started to expand rapidly, and during 10 years of the Syrian crisis, U.S, different legislative departments sanctioned 750 Syrian officials, government institutions, and private companies which were involved in supporting the Syrian regime (Marzouq, 2011). Many countries joined the U.S, by imposing sanctions on the Syrian regime, these sanctions were not extensive like the U.S, ones. The list of sanctions sender countries included; Turkey, Switzerland, Australia, Canada, Japan, and the U.K. Most of those sanctions were about freezing bank accounts of persons from the Syrian government or supporting the government, others were entities of the government, or were affording the Syrian government with needed financial and logistic support, also they imposed trade sanctions on Syria except humanitarian needs, and equipment's (Moret, 2015).

\section{Multilateral sanctions}

Besides sanctions, which were imposed by countries individually, there were sanctions that were imposed by international organizations multilaterally; the beginning was with the European Union, which started targeted sanctions on a group of Syrian officials in May 2011. Later in November 2011, the Arab League States imposed sanctions on the Syrian government, froze Syria`s seat in the League, and stopped the relations with Syria`s banking system besides some other measurement. The Arab League States were not able to agree on expanding sanctions later, and many Arabic countries tried to bring back their relations with Syria as if there are no human rights violations or a crackdown from the Syrian regime on civilians. Nevertheless, from the beginning, countries like; Lebanon and Iraq were not cooperating with the Arab League to activate those sanctions. (Abu Al-Rous, 2019). As for the European Union; its sanctions continued and were witnessing some up-downs in level or targeting cases. This was due to many reasons, the main one of them were the EU, attempt to reach a nuclear deal with Iran, the second was the emergence of ISIS, and the consequences of announcing the "Islamic Caliphate" on the regional and international security. However, EU, sanctions on the Syrian regime reached between 2011 until 2019 to more than 340 cases of sanction; ("Sanctions against the regime extended by one year", 2020).

As for the most important international organization represented in the UN, it failed to intervene positively in the Syrian conflict, neither with regard to ending the conflict nor with regard to stopping the violations perpetrated by the various parties, especially by the Syrian regime, as it is still the politically recognized party, and is represented in international institutions. Although the main mission of the United Nations according to its principles is the maintenance of international peace, even if it necessitates imposing sanctions on certain countries. The international system has not been able to implement any provisions related to the protection of Syrian civilians and pressure the Syrian regime to change its behavior, (the anniversary of the first "VETO" how did Russia's most powerful weapon support Assad? 2020).

\section{Data of US and EU Sanctions}

Since the EU, and U.S, are on the top of sanctions senders, I would try to express their targets in a few figures, those figures would show the differences between both sides concentrate, and it will show the changes of sanctions` levels according to dates. 


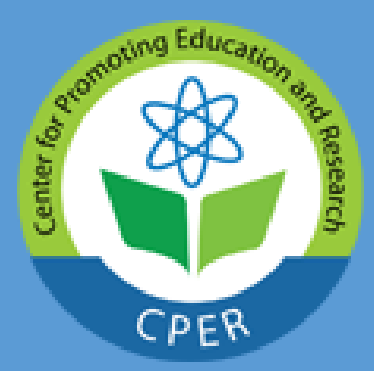

International Journal of Business and Applied Social Science (IJBASS)

E-ISSN: 2469-6501

VOL: 7, ISSUE: 1

January/2021

DOI: 10.33642/ijbass.v7n1p6

\section{(C) Center for Promoting Education and Research (CPER) USA}

Www.cpernet.org

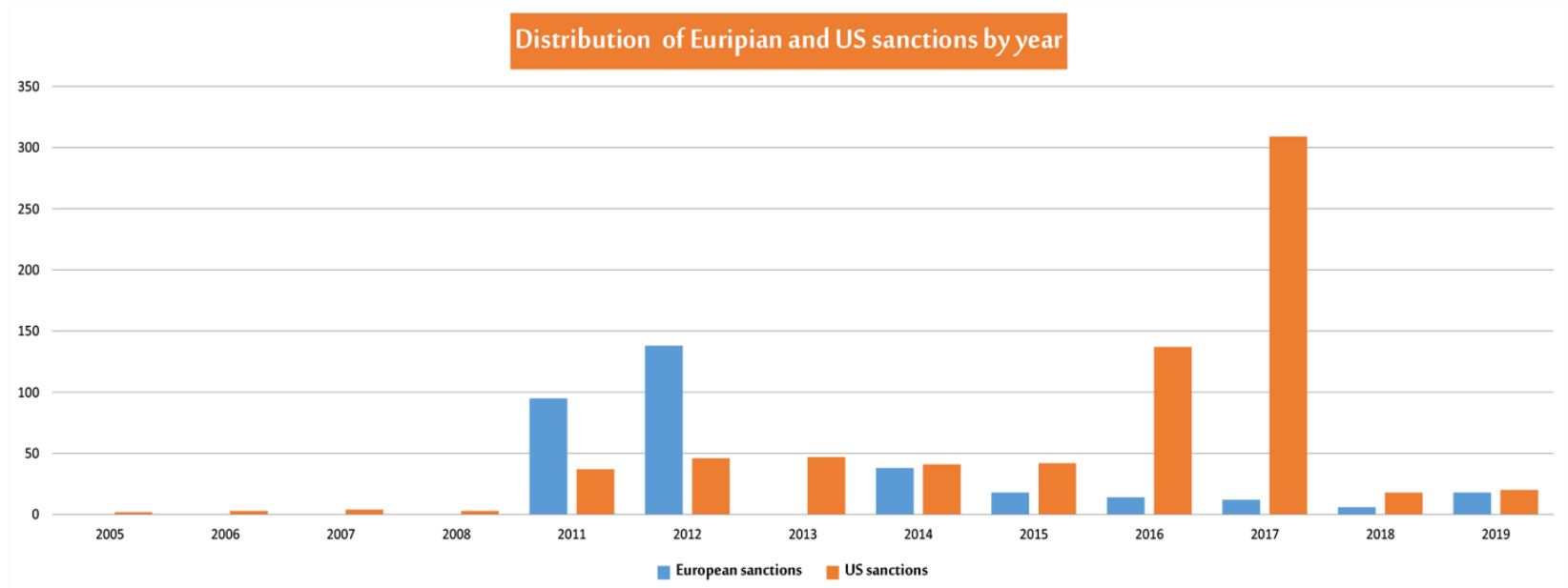

Figure 1. The figure has been formed by the author depending on analyzing 1200 sanctioned entities, based on the Syria Report data base on sanction on Syria)

Data of the European Union illustrate that the EU sanctions presence itself. (Al-Ahwaz, 2016). Also, the emergence of the against Syria are in total less than half of sanctions imposed by Islamic State and its control over major cities in Iraq and Syria the United States, especially in 2013- 2015 "when only in 2014, was another factor in the hesitation of the European previous European sanctions were renewed, and no new Union regarding the collapse of the regime in Syria (Foreign sanctions were imposed on the regime. The EU was not in fighters in ISIS: How many of them are left in Iraq and Syria? favor of sharply escalating its policy against the regime, since 2019). "The serious threat of economic sanctions and the the EU was engaged in a negotiation process with Iran about possible repercussions of this threat is justified by the risk of the latter nuclear file, and the EU did not want to put severe the continuing war in Syria and the continuing existence of the pressure on Iran and its allies in the region or on the Iranian Islamic State in its present form" (RAND Corporation, 2017).

\section{the targeted groups by European sanctions}

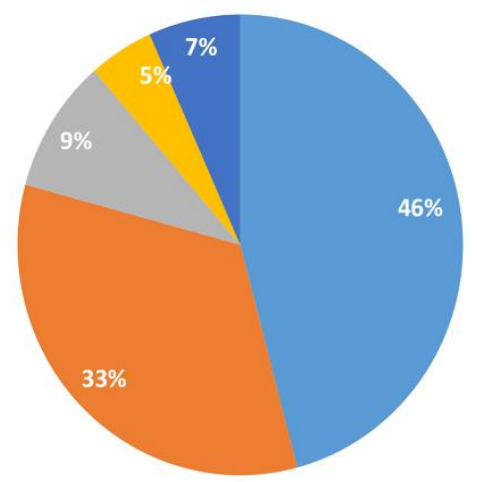

Security/military institutions

Trade foundations

Service institutions

Banking institutions

Oil institutions

Figure 2. The figure has been formed by the author depending on analyzing 1200 sanctioned entities, based on the Syria Report data base on sanction on Syria

Figure (2) shows that the EU has focused on three key sectors in Syria, which are military, security officers, and officials in the Syrian government and departments by a percentage of nearly $62 \%$. These are smart sanctions targeting the structure of the Syrian regime. Regarding the distribution of sanctions according to government sectors, we find that European sanctions have largely targeted the Syrian oil sector, in $46 \%$ of cases, and trade institutions and companies with 33\%, both sectors are the main source of income to the Syrian regime. 


\section{Groups targeted by US sanctions}

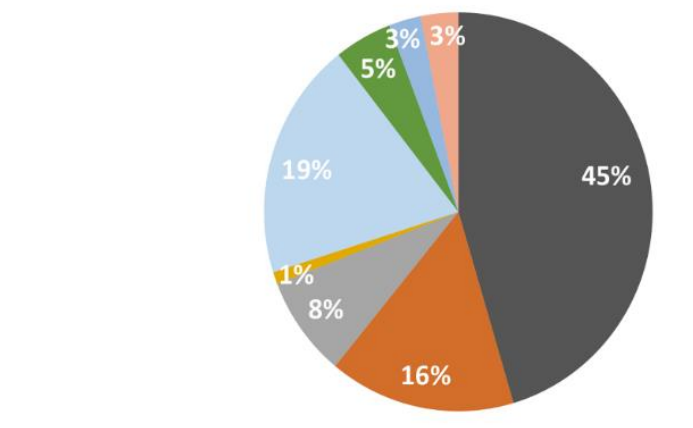

Technocrats

- Terrorist Organizatan

Businessman

Politician

Figure 3. The figure has been formed by the author depending on analyzing 1200 sanctioned entities, based on the Syria Report data base on sanction on Syria)

Figure (3) shows that the US sanctions focused heavily private sector the USA tries to make a siege around the Syrian on the technocrats by about $45 \%$, in addition to the private regime, preventing dealing with the regime, whether in their sector with $19 \%$ of cases. By focusing on technocrats, and the personal or governmental capacities.

\section{US sanctions on Syrian government agencies}

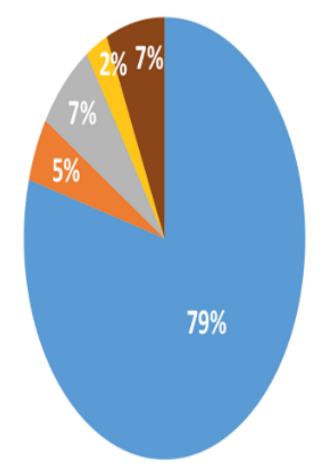

Figure 4. The figure has been formed by the author

We notice from the US sanctions on the sectors of the Syrian government that there is intense targeting of the security and military institutions by around $80 \%$, which is demonstrating how much the military and security branches are involved in the abuses committed against civilians.

\section{Impacts of sanctions}

Syria is witnessing one of the worst internal wars in the world in many decades. Since the war and sanctions are progressing in a parallel way in Syria, the effects of sanctions cannot be researched independently. Yet some indicators may give some of their effects like the, for example, the war's effect only on the physical capital reached to more than 442 billion USD, also sanctions and the war led to a shrink in the
Syrian economy 54\%. The Syrian imports and exports share in the GDP dropped from $45 \%$ to $27 \%$ in 2018 , but this $27 \%$ was a very low amount. Also importing to Syria, for example, the EU, dropped from $25.8 \%$, at the value of 4.9 billion USD to $10.7 \%$ at 0.7 billion USD in the same period. Another indicator is represented by the foreign companies that left the Syrian oil market, in this regard at the beginning of the war 14 foreign companies left Syria. Sanctions were effective in pushing foreign companies to leave, also they were active in forbidding holding contracts to repair Syrian oil fields and pipelines, or selling it in the international markets. (pp. 53, 54, 55. ESCWA, 2020). Another indicator of sanctions impact can be followed through the decrease that took place in Syrian GDP during the 
years 2012- 2013, since in those years, and especially 2012, most of the Syrian incomes were still in the hand of the Syrian government, even the oil fields production was reaching to the government-controlled areas and refineries. In this regard, the Syrian GDP dropped from 60 billion USD to 27 billion USD. (Syria GDP-Gross Domestic Product 2018, 2020)

\section{Conclusion}

Still, the scientific community is discussing the effectiveness of sanctions on authoritarian regimes, the arguments and discussions would not stop since till now all works on sanctions have not shown clear cut regarding their impact on the behavior of countries that are violating international laws and human rights on their lands. The argument is progressing since there is no international correspondence and coincidences on the subject. Scholars among themselves and policymakers are judging sanctions success possibilities, moreover, the argument is still going around whether sanctions are used as a political tool by great powers, especially the United States of America. Nevertheless, the best theoretical model I found that can be applied to discuss sanctions is the one used by Clifton, Bapat, and Kobayashi, 2014, which is called TIES work. In the TIES paper, the researchers used the spatial model, through the data they used they concluded that authoritarian regimes would not compel with sanctions senders if those sanctions would cause their collapse.
This case can be seen in the example of sanctions on Iran, Libya, and Syria, where the Syrian regime is facing sanctions unilaterally from the U.S and multilateral sanctions in 1986, also in 2003. During the case of multilateral and not fatal sanctions, we saw that the Libyan, as well the Syrian regime changed some of their behaviors especially after 1991, and 2001 for Libya, and 1986, and 2003, sanction cases on Syria. Nevertheless, after 2011 the sanctions imposed from the U.S, and the EU, came among the Syrian people started demanding real political changes in the country, here the Syrian regime took the most resorted decision of authoritarian regimes, by acting based on "if responding positively to sanctions, so it means the end of its rule. Consequently, resisting would be more worthy for the ruling elite than surrounding the well of the western countries as the regime portrays the case of sanctions.

Since the Syrian regime took, this decision there would be no choice for the international community, except than proceeding in sanctioning policy in parallel with complex guidance for the political solution of the crisis in the country. The breaking point of all side`s position is still unclear, nor the regime, or the U.S, EU, and other senders of sanctions, or the Syrian people who are suffering the consequences of the unprecedented levels of sanctions, as a result of the tide connection between the sanctioned entities and the Syrian intuitions in general.

\section{REFERENCES}

(2016) The UNOG.ch website.

[Online].Available: https://www.unog.ch/80256EDD006AC19C/(httpPages)/17C8E6BCE10E3F4F80256EF30037D733?Open Document

Talmon, S, "The Security Council as World Legislature", the American Journal of International Law,. Vol.20, pp. 175-193. 1999.

(2016), United Nations News website. [Online]. Available: https://news.un.org/en/story/2016/05/528382-un-sanctions-whatthey-are-how-they-work-and-who-uses-them

M. Russell, "EU sanctions: A key foreign and security policy instrument, "in European Parliament, 2018, pp. 3-4.

Clifton T, Bapat, N, and Kobayashi Y, "Threat and Imposition of Economic Sanctions 1945-2005: Updating the TIES Dataset", Conflict Management and Peace Science" Conflict Management and Peace Science, vol. 31, no. 5, pp. 541-558. 2014.

L. Savey J, "Unilateral Sanctions: An Effective Foreign Policy Tool in Myanmar?" Willamette Law Review, Vol. 50 , No. 3. 2014 ,

D. Houghton, “Us-Iranian Relations, Future and Past”, European Political Science, volume 13, pp. 376-379. 2014.

D. Patrikarakos, Nuclear Iran: The Birth of an Atomic State, Bloomsbury, London, United Kingdom Publishing PLC. 2012, (2018) Country Economy website. 2020. Iran GDP - Gross Domestic Product [online]. Available at:

<https://countryeconomy.com/gdp/iran> [Accessed 27 November 2020].

(2019) Africa Gate News website , 50 facts about Libyan oil, from discovery to nationalization, [online]. Available at: https://www.afrigatenews.net/article/50-\%D9\%85\%D8\%B9\%D9\%84\%D9\%88\%D9\%85\%D8\% A9-\%D8\%B9\%D9\%86- 


\section{(c) Center for Promoting Education and Research (CPER) USA}

WWW.cpernet.org

Y. Zoubir, "The United States and Libya: From Confrontation to Normalization. Middle East Policy, vol. 13, pp.48-70. [online]. Available at: https://doi.org/10.1111/j.1475-4967.2006.00250.x

Crisis Group website. (2010). Libya/Chad: Beyond Political Influence. Brussels: Crisis Group. [online]. Available at: https://www.crisisgroup.org/africa/central-africa/chad/libyachad-beyond-political-influence

A. Bangura Assessing Barack Obama"s Africa Policy: Suggestions for Him and African Leaders, Lanham, Maryland, United States, University Press of America, 2014.

Sloan, Stephen, and Sean K. Anderson. Historical Dictionary of Terrorism. Google Books, 2nd ed., Lanham, United States, Scarecrow Press, p. 604, 2009,

Reuven, E, Terrorism as a Preferred Instrument of Syrian Policy. The International Institute for Counter-Terrorism (ICT), Dec 1998. [online]. Available at: https://www.ict.org.il/Article/754/Terrorism\%20as\%20a\%20Preferred\%20Instrument\%20

Elseid Hussein, H. "The Egyptian - Israeli Peace Treaty of 1979 and its Impact on Egypt"s Regional Role," Journal of Historical Studies, no, 117-118, Jan 2012.

A. Rochefort, D, "U.S. Definition of Terrorist States: a Rhetorical Analysis and critique," the Forty-Sixth Annual Meeting of the International Studies Association, 2005, Panel on Terrorism, Wars on Terror p. 7.

A. Jamal. (2015) "40 Years after the Civil War in Lebanon". Non Post. [online]. Available at:

https://www.noonpost.com/content/6265

(1986) The Spectator website. [Online]. Available at: http://archive.spectator.co.uk/article/1st-november-1986/13/who-washindawi-working-for

(1986) The Nytimes website. [Online]. Available at: https://www.nytimes.com/1986/10/25/world/britain-breaks-syrian-tiescites-proof-terror-role-el-al-suspect-convicted-us.html

J. Kreutz, "Hard Measures by a Soft Power? Sanctions policy of the European Union 1981-2004," Bonn International Center for Conversion, no. 45. 2005. [Online]. Available at: https://www.bicc.de/uploads/tx_bicctools/paper45.pdf

S. Scott, "British foreign policy towards Syria; its Importance, its distinctiveness and its relations to the policy of the other actors in the region" University of St Andrews. pp. 180-215, 2016.

M. Jeremy, Syria: Background and U.S. Relations, Congressional Research Service. (March, 2010), [Online]. Available at: https://digital.library.unt.edu/ark:/67531/metadc503617/m1/1/high_res_d/RL33487_2010Mar03.pdf

M. Al-Himish, The Syrian economy in forty years: An analytical study of the economic and social developments in Syria 1971 2010. Beirut, Lebnon: Al Maaref Forum, p. 60, 2011.

M. Nuruzzaman, "Rethinking Foreign Military Interventions to Promote Human Rights: Evidence from Libya, Bahrain and Syria," Gulf University for Science and Technology, Kuwait, vol. 48, no. 3, 2015.

M. Bosco. "the Assassination of Rafik Hariri: Foreign Policy Perspectives". International Political Science Review, Vol. 30, no. 4, pp. 349-361, Nov. 1999.

(2015) Arabic.cnn website. [Online]. Available at: https://arabic.cnn.com/middleeast/2015/06/28/isis-one-year-after-khilafadeclaration.

(2011) Aljazeera website. [Online]. Available at:

https://studies.aljazeera.net/ar/reports/2011/11/2011111910249163525.html?fbclid=IwAR0S6BBXrfzf0iYz2uU4dWONXbg2Z HgfGDUeFk2qn-4NUlv7gMFC0VMfW7E.

E. Moret, "Humanitarian impacts of economic sanctions on Iran and Syria," European Security, vol 24, pp. 120-140, Nov. 2014.

K. Abu Al-Rous, Developments of the Arab stand regarding Syrian regime. Gaza Palestine, The Palestinian Center for Policy Research and Strategic Studies, 2019, [Online]. Available

at: https://www.masarat.ps/article/5095/\%D8\%AA\%D8\%B7\%D9\%88\%D8\%B1\%D8\%A7\%D8\%AA-

\%D8\%A7\%D9\%84\%D9\%85\%D9\%88\%D9\%82\%D9\%81-\%D8\%A7\%D9\%84\%D8\%B9\%D8\%B1\%D8\%A8\%D9\%8A-

\%D9\%85\%D9\%86-\%D8\%A7\%D9\%84\%D9\%86\%D8\%B8\%D8\%A7\%D9\%85-

\%D8\%A7\%D9\%84\%D8\%B3\%D9\%88\%D8\%B1\%D9\%8A

(2020) Consilium website. [Online]. Available at: https://www.consilium.europa.eu/en/press/press-releases/2020/05/28/syriasanctions-against-the-regime-extended-by-one-year/\#. 
(2020) Syriatv website. [Online]. Available at:

https://www.syria.tv/\%D9\%81\%D9\%8A-\%D8\%B0\%D9\%83\%D8\%B1\%D9\%89-

\%D8\%A7\%D9\%84\%D9\%81\%D9\%8A\%D8\%AA\%D9\%88-\%D8\%A7\%D9\%84\%D8\%A3\%D9\%88\%D9\%84\%D9\%83\%D9\%8A\%D9\%81-\%D8\%AF\%D8\%B9\%D9\%85-\%D8\%B3\%D9\%84\%D8\%A7\%D8\%AD\%D8\%B1\%D9\%88\%D8\%B3\%D9\%8A\%D8\%A7-\%D8\%A7\%D9\%84\%D8\%A3\%D9\%82\%D9\%88\%D9\%89\%D8\%A7\%D9\%84\%D8\%A3\%D8\%B3\%D8\%AF\%D8\%9F

(2019) BBC. Website. [Online]. Available at:Bhttps://www.bbc.com/arabic/middleeast-47293415.

B. Connable, N. Lander, Kimberly, "Beating the Islamic State Selecting a New Strategy for Iraq and Syria," Rand Cooperation, pp. 59-60, 2017.

R. Hinnebusch, "Syria at War: Eight Years on," ESCWA Beyrut Lebnon, p. 47.

(2020) The Country Economy website. [Online]. Available at: https://countryeconomy.com/gdp/syria?year=2020 